-书评・

\title{
《江苏植物志》修订再版，令人耳目一新
}

\author{
马克平 ${ }^{*}$
}

(中国科学院植物研究所植被与环境变化国家重点实验室, 北京 100093)

\section{Revised version of Flora of Jiangsu with refreshing additions}

Keping Ma*

State Key Laboratory of Vegetation and Environmental Change, Institute of Botany, Chinese Academy of Sciences, Beijing 100093

《江苏植物志》上册和下册分别于1977年和 1982年出版，时隔30年后得以修订再版，可喜可 贺。总览新版《江苏植物志》1-5卷(2013-2015年出 版, 刘启新主编), 令人耳目一新。

第一，收载江苏省植物的类群数量和范围增 加。与原《江苏植物志》相比, 修订版增加了苔藓 植物; 而且维管植物种数也增加了近 $1 / 3$ 。原版收载 维管植物 197 科 2,350 种, 修订版收录 235 科3,132种。 比较好地反映了江苏植物分类学的研究进展。

第二, 利用《中国植物志》、Flora of China和 《中国生物物种名录》(2011)等新的研究成果, 订正 了原版中存在的分类学错误, 并将最新的分类学研 究成果整合到修订版中。科学性显著提高。

第三，被子植物科的排列主要参考Cronquist 分类系统(1981), 部分科的排列参考了APG III系统 (2009), 体现了与时俱进的时代特色。

第四, 修订版第1卷列出了全部收录种的凭证 标本(以野生植物为主) 的采集号和收藏的标本馆, 附有不同植物资源类别的物种名录和高等植物常 用形态特征术语和图解等，提供了丰富的信息。

第五, 根据标本、野外调查记录和文献, 细化 了植物在江苏的分布信息, 一般到市(县)级; 而且 对江苏省已经发现野外灭绝或近于灭绝的物种如 中华水非(Itoetes sinensis)、珊瑚菜(Glehnia littoralis)、南京木蓝 (Indigofera chenii)、钟山草 (Petitmenginia matsumurae) 等明确指出了它们的生 存现状，为保护和规划提供确切信息。

第六, 根据档案记载等, 清楚地补充记录了
《江苏植物志》原版编写过程、编写人员和分工, 改 正了特殊历史时期只署名“江苏省植物研究所”的缺 憾，还历史以本来面目。

第七，修订版全书版式新颖美观，每种植物都 配有一张线描图, 且随种类插附, 方便读者使用。 在艺术设计与专业实用结合上达到新水平。

在《中国植物志》和Flora of China等出版后, 省级植物志是否还有必要继续编？吴征捡院士在 所写之序中明确指出 “我觉得植物志需要继续做, 而且要深入做”。省级植物志如何深入来做? 笔者 提出三点建议供参考: (1)内容上保持现有省级植物 志的样式, 适当补充优化, 强调每种植物都要标出 凭证标本号与保存的标本馆, 便于查阅核实。而且 省内的分布尽量细化到县一级, 有条件时提供分布 点信息, 便于研究和实际应用, 鼓励绘制分布图。 (2)改变目前资料手册型的志书形式, 编写研究型植 物志, 在现有内容的基础上, 增加科属研究进展评 述和讨论方面的内容。(3)同时出版电子版, 特别是 在线形式, 内容可以更加丰富, 包括多媒体资料和 重要的文献信息等, 并不断更新。

目前, 除陕西和吉林省外，各个省都出版了或 正在编研省级植物志, 有些省份如江苏、内蒙古和 台湾等出版了修订版; 有些市如深圳和温州等出版 了市域植物志; 有些县如湖北竹溪和通城县的植物 志已经出版, 山东邹县和云南新平的植物志正在编 写等。这些植物志的编研和出版发行, 为植物多样 性保护和利用提供了丰富可靠的信息, 值得大力提 倡和鼓励。

\footnotetext{
*通讯作者 Author for correspondence. E-mail: kpma@ibcas.ac.cn
} 